\title{
The Secularisation Thesis Recast: Christianity in Modern China and South Korea
}

\author{
Jemima A.H. Baar \\ Faculty of Divinity, University of Cambridge, Cambridge, United Kingdom \\ jemimabaar@gmail.com
}

\begin{abstract}
Steve Bruce's and Karel Dobbelaere's secularisation theses - that industrialisation, urbanisation, societalisation, and rationalisation erode religion on macro-, mesoand micro-levels - can be challenged by reference to the growth and vitality of Christianity in China and South Korea. Christianity propelled economic growth and political change in South Korea at the end of the twentieth century, and has recognised potential in China. Religious institutions play critical roles in contemporary South Korean and Chinese communities. Although in an economically dynamic age permeated by scientific thinking, Christianity thrives in the private sphere in China. The plateauing of the growth rate of South Korean Christianity in recent decades coincides with widespread stability and prosperity in the country, which may have reduced the psychological and practical needs for religion. Thus, the Secularisation Thesis ought to be recast: social stability and prosperity better explain religious decline than industrialisation, urbanisation, societalisation, and rationalisation.
\end{abstract}

\section{Keywords}

Secularisation Thesis - Christianity - China - South Korea

\section{Introduction}

The Secularisation Thesis postulates that modernity precipitates a decline in the social significance of religion. Yet the considerable religious vitality evident in China and South Korea, the world's second and eleventh largest economies, 
respectively, challenges this proposition. ${ }^{1}$ From 1962 to 1992, South Korean GDP rose an average $9 \%$ annually, from US $\$ 2 \mathrm{bn}$ to $\$ 276.8 \mathrm{bn} .^{2}$ During this time, its combined Protestant and Catholic communities grew from 1.32 million to 10.8 million, ${ }^{3}$ as the total population increased from 26 million to 43 million. ${ }^{4}$ Although the rate of growth has slowed, South Korea's total Christian population numbered over 13 million in $2015 \cdot{ }^{5}$ Religious practice in South Korea is animated and lively. As Dave Hazzan observes, 'Protestant services are rarely subdued... with people falling into trances, speaking in tongues, and loudly proclaiming their allegiance to God,. ${ }^{6}$ Estimating the size of China's Christian population is challenging due to the number of unregistered churches and the lack of census data on religion. However, a 2011 Pew Forum study suggests that it numbers 67 million, ${ }^{7}$ compared to approximately 4 million in $1949 .{ }^{8}$ Despite heavy state monitoring - every crevice in Beijing's Church of the Immaculate Conception is equipped with a security camera - its pews are full every Sunday.

\section{Background: The Secularisation Thesis}

Fragile secularisation theses are those that propose universalising theories but are based on overwhelmingly European and Christian data. Although Peter Berger later retracted his thesis, ${ }^{9}$ his early writing, containing phrases such as 'insofar as this is a global trend, ${ }^{10}$ is representative of this thinking. Scholars

1 'GDP Ranked by Country 2020', World Population Review (2020) http:// worldpopulationreview.com/countries/countries-by-gdp/.

2 Sung-Ho Kim, 'Rapid Modernisation and The Future of Korean Christianity', Religion 32 (2002), 27-37, at p.28.

3 Ibid., p.27.

$4 \quad$ United Nations Department of Economic and Social Affairs (2019), 'Population Dynamics', https://population.un.org/wpp/.

5 Statistics Korea, Number of Religious People Affiliated to Protestantism in South Korea Form 1985 To 2015 (Seoul: Ministry of Culture, Sports and Tourism, 2020); and Statistics Korea, Number of Religious People Affiliated to Catholicism in South Korea Form 1985 To 2015 (Seoul: Ministry of Culture, Sports and Tourism, 2020).

6 Dave Hazzan, 'Christianity and Korea' The Diplomat (2016) https://thediplomat. com/2016/o4/christianity-and-korea/.

7 'Global Christianity: A Report on the Size and Distribution of the World's Christian Population', Pew Research Center (2011).

8 The sum of the Protestant population of 700,000, Shining Gao, 'The Sacred Canopy in China', Journal of The American Academy of Religion, 85 (2017), 1132-1136, at p.1134; and the Catholic population of 3.2 million, Henry Kamm, 'Pope Calls on China to Renew Its Relations with The Church', New York Times (1982).

9 John Clammer, 'Secularization and Religious Change in Contemporary Asia', Asian Journal of Social Science, 12 (1984), 49-58, at p.51.

Peter Berger, The Sacred Canopy: Elements of A Sociological Theory of Religion (New York: Anchor Books, 1967), p.146. 
of Asian Christianity (and, indeed, scholars of Christianity in non-Western contexts more broadly) tend to reject notions of a universal process of secularisation on the basis that religion plays a fundamentally different role in non-Western contexts. For example, John Clammer cites the enduring presence of spirituality and rituals ${ }^{11}$ and the close links between ethnicity and religion ${ }^{12}$ in South and Southeast Asia to argue that religion in Asia cannot be 'slotted with ease into the box of the Western concept of secularisation. ${ }^{13}$

However, there exist more nuanced secularisation theses such as those of Steve Bruce and Karel Dobbelaere, which do not intend to make universalising claims but nevertheless try to link elements of modernity with a decline in religiosity. Bruce characterises his thesis as 'an attempt to explain a historically and geographically specific cluster of changes' 14 and argues that, therefore, 'There is no Secularisation Theory. There is a cluster of testable explanations'. ${ }^{15}$

Bruce's 'testable explanations' are as follows: modernity, which he defines as encompassing industrialisation, urbanisation, societalisation, and rationalisation, causes structural and social changes that have rendered religion at best, privatised, and at worst, obsolete. ${ }^{16}$ Both Bruce and Dobbelaere contemplate religion being eroded at three levels. At a macro-level is 'societal secularisation, ${ }^{17}$ whereby religion loses influence over large-scale political decisions. At a meso-level, religious institutions lose 'social standing', 18 their ability to maintain relevance and project themselves within communities diminishes. At a microlevel, both posit that religion may continue to operate in private following its retreat from the public sphere. ${ }^{19}$ However, they predict that, eventually, there will be 'a decline in the extent to which people engage in religious practices... and conduct other aspects of their lives in a manner informed by beliefs'. ${ }^{20}$

The notion that industrialisation, urbanisation, societalisation, and rationalisation are universal by-products of modernity is relatively uncontroversial. In the past century, more regions of the world have become industrialised, ${ }^{21}$

\footnotetext{
$11 \quad$ John Clammer, 'Secularization and Religious Change in Contemporary Asia', p.53.

12 Ibid., p.54.

13 Ibid., p.51.

14 Steve Bruce, God Is Dead: Secularisation in The West (London: Blackwell Publishing, 2002), p.37.

15 Steve Bruce, God Is Dead: Secularisation in The West, p.38.

16 Ibid., p.2.

17 Karel Dobbelaere, Secularisation: An Analysis at Three Levels (Brussels: P.I.E. - Peter Lang, 2002), p.24.

18 Steve Bruce, God Is Dead: Secularisation in The West, p.3.

19 Karel Dobbelaere, Secularisation: An Analysis at Three Levels, p.34.

20 Steve Bruce, God Is Dead: Secularisation in The West, p.3.

$21 \quad$ Industrial Development Report (Vienna: United Nations Industrial Development Organisation, 2017).
} 
and, correspondingly, there has been considerable urbanisation and societalisation: the world's urban population grew from 751 million in 1950 to 4.2 billion in $2018 .^{22}$ The prevalence of rationalisation is less clear, as will be examined later in this article, but there is arguably a greater emphasis on scientific reasoning in modern society than there was a century ago.

This article seeks to determine whether these effects of modernisation the so-called 'testable explanations' - necessarily lead to a decline in religiosity, as Bruce and Dobbelaere contend. South Korea and China are chosen because they have experienced immense economic growth and social changes in the past century, alongside significant growth of their Christian populations. Thus, this article aims, first, to challenge the application of the Secularisation Thesis in South Korea and China, and thereby substantiate the existing concerns about the thesis voiced by scholars of religion in non-Western contexts. Second, it intends to ascertain whether the elements of modernity that Bruce and Dobbelaere identify lead to the secularisation of societies, or whether, in fact, other factors may better explain religious decline.

\section{The Secularisation Thesis Recast}

South Korea and China challenge Bruce and Dobbelaere's theses at all three levels. First, while neither country has had a hegemonic religious institution similar to the Catholic Church in medieval Europe, Christianity has been a demonstrable force in propelling economic growth and political change in South Korea and has had recognised potential in China.

Second, churches in both countries play important roles in their respective communities, such as caring for vulnerable groups. If anything, it seems that urbanisation has invigorated them at a meso-level. Bruce contemplates temporary 'exceptions' to his thesis following seismic social change, and might respond that China and South Korea's examples should be categorised as such. ${ }^{23}$ It is too early, and not enough data has been gathered, to conclude definitively either way, although it is clear that religious institutions currently play an important role in South Korean and Chinese communities in spite of, and, indeed, because of urbanisation.

Third, particularly in China, Christianity thrives in the private sphere. Dobbelaere and Bruce may argue that this is consistent with their theses as it suggests that 'religious authorities have lost control over the beliefs, practice, and moral principles of individual persons.' ${ }^{24}$ However, it is suggested, with

Revision of World Urbanization Prospects (Vienna: United Nations Department of Economic and Social Affairs, 2018).

23 Steve Bruce, God Is Dead: Secularisation in The West, p.36.

24 Karel Dobbelaere, in Russell Sandberg, ed, Religion, Law and Society (Cambridge: Cambridge University Press, 2014), p.75. 
reference to Fenggang Yang's 'tripartite' system of religion ${ }^{25}$ that the privatisation of religion in China is likely due to restrictive political environments rather than modernity.

That said, the growth rate of South Korean Christianity has plateaued in recent decades. ${ }^{26}$ This coincides with widespread stability and prosperity in the country, which may have reduced the psychological and practical needs for religion. This may suggest that social stability and prosperity better explain religious decline than industrialisation, urbanisation, societalisation, and rationalisation.

\section{Macro-Level: Social Differentiation}

Bruce suggests that secularisation occurs at a macro-level when religion loses its influence over 'the operation of non-religious roles and institutions such as those of the state and the economy'.27 This echoes Emil Durkheim's concept of 'differentiation': the process by which secular society assumes control over institutional functions that were previously performed by religious establishments. ${ }^{28}$ However, modern South Korean, and to an extent Chinese, churches have become politically and socially significant notwithstanding industrialisation and urbanisation. In South Korea, both the Protestant and Catholic churches have stimulated modernising changes, such as economic growth and democratisation. ${ }^{29}$ In China, Christianity has not directly impacted politics, but, notably, its potential has been recognised by top-level officials.

\section{Protestantism and Economic Activity}

There is a perception in East Asia, which was realised in South Korea, that Protestantism can support economic activity. South Korea's Protestant population grew from 736,ooo to 3.2 million between 1962 and 1970, a period of significant economic growth. ${ }^{30}$

The following table shows the growth rates of Protestantism and Catholicism in South Korea between 1962-2015:

Fenggang Yang, Religion in China: Survival and Revival Under Communist Rule (Oxford: Oxford University Press, 2012), p.85.

26 Grace Davie, Europe: The Exceptional Case (London: Darton, Longman and Todd, 2002), p.125.

27 Steve Bruce, God Is Dead: Secularisation in The West, p.3.

28 Emil Durkheim, The Elementary Forms of Religious Life, trans. Joseph Ward Swain (London: George Allen \& Unwin, 1915), p.308.

29 Grace Davie, Europe: The Exceptional Case, p.127.

$30 \quad$ Sung-Ho Kim, 'Rapid Modernisation and The Future of Korean Christianity', p.27. 
TABLE 1 The growth rates of Protestantism and Catholicism in South Korea between 1962-2015

\begin{tabular}{|c|c|c|c|c|}
\hline & $\begin{array}{l}\text { Protestantism } \\
\text { Membership }\end{array}$ & Rate (\%) & $\begin{array}{l}\text { Catholicism } \\
\text { Membership }\end{array}$ & Rate (\%) \\
\hline 1962 & $736,0 \circ 0$ & & 590,000 & \\
\hline 1970 & $3,192,0 \circ 0$ & 333.7 & $779,0 \circ 0$ & 32.0 \\
\hline 1985 & $6,489,000$ & $103 \cdot 3$ & $1,870,0 \circ \circ$ & 140.1 \\
\hline 1995 & $8,760,000$ & 35.0 & $2,95 \circ, 000$ & 57.8 \\
\hline 2005 & $8,620,000$ & -1.6 & 5,15 ०,০০০ & 74.5 \\
\hline 2015 & $9,680,0 \circ 0$ & 12.3 & 3,89o,০০০ & -24.5 \\
\hline
\end{tabular}

All values are rounded.

SOURCES: $1962-1970 ;^{31}$ PROTESTANTISM $1985-2015 ;{ }^{32}$ CATHOLICISM $1985-2015^{33}$

It is important to note that there is relatively scarce data for the period between 1962 and 1985 , and that therefore, it is difficult to construct a table conveying the growth rates of Protestantism and Catholicism in South Korea in equal yearly increments. Nevertheless, meaningful conclusions can be drawn from this data. That the growth rate of Protestantism was $333.7 \%$ over just eight years is particularly significant. This has led some, including Konstantine Vassiliev, to posit that South Korea is a modern example of Max Weber's 'Protestant Ethic' theory, which advances that there exists a relationship between ascetic Protestantism and the 'spirit' of modern capitalism. ${ }^{34}$ Kirsteen Kim is more cautious, contending that 'Weber's argument presupposes a large mass of practising Christians.' ${ }^{35}$ But in Korea, Christians comprised just $6 \%$ of the population in 1962, and a range of other factors were behind its economic boom, such as state-led emphasis on export expansion and import substitution. ${ }^{36}$ She argues convincingly, 'the influence of Christianity in South Korea has been via the leadership it has offered, rather than by its widespread practice. ${ }^{37}$

A similar table was first constructed by Sung-Ho Kim (Ibid., p.27). The increments from 1962-1970 are Kim's; the increments from 1985 onwards are my own.

32 Statistics Korea, Number of Religious People Affiliated to Protestantism in South Korea Form 1985 To 2015 .

33 Statistics Korea, Number of Religious People Affiliated to Catholicism in South Korea Form 1985 To 2015 .

34 Konstantine Vassiliev, 'Industrialization and Christianity: The Twin Engines of Korean Modernity', Korea Review of International Studies (2005), 79-102, at p.9o.

35 Kirsteen Kim, 'Christianity's Role in The Modernization and Revitalization of Korean Society in The Twentieth-Century', Religion, 4 (2010), p.228.

36 Kwan S. Kim, 'The Korean Miracle (1962-1980) Revisited: Myths and Realities in Strategy and Development', Helen Kellogg Institute for International Studies (Notre Dame: University of Notre Dame, 1991), p.2. Society in The Twentieth-Century', p.228. 
New adherents associated Protestantism with the U.S., the prosperous guarantor of South Korea's safety against the communist North. Priests appealed to the South's desire to modernise and differentiate itself from the North by preaching what Andrew Kim terms the 'theology of prosperity', ${ }^{38}$ emphasising, as Vassiliev outlines, Protestantism's 'proven record of success in industrialised society', and claiming that 'material abundance, health, and other blessings follow the righteous' ${ }^{39} \mathrm{~A}$ genuine belief emerged amongst South Koreans that, 'if they could repeat this record of faith, they would be granted similar prosperity' to that enjoyed in the West, which galvanised new members. ${ }^{40}$

The Church also provided practical support for economic activity. Churches were run not 'as charities or clubs but as businesses', and organised community networking opportunities. ${ }^{41}$ This, Kirsteen Kim argues, 'inculcated capitalist thinking. ${ }^{42}$ Vassilievgoesfurther, positing thatChristianity helped tore-evaluate traditional views on women's social role and their contribution to such important areas as education, work, and family life', and therefore, encouraged social mobility and generated a more productive workforce. ${ }^{43}$

Unlike the Protestant endorsement of individualism and economic activity, the Catholic Church promoted social justice. ${ }^{44}$ The Korean War had ended only a decade earlier and Koreans in the South, many of whom were northern refugees, were 'preoccupied by anti-Communism' and therefore, deeply suspicious of Catholicism's ideas about social change. ${ }^{45}$ Protestantism appeared to embrace modernity, Western ideals and economic growth. It echoed the popular mood: 'although they aspired to democracy, most South Koreans, including Christian pastors, put a higher value on national security and economic growth:46 The popularity of the Protestant Church's rhetorical and practical support for economic activity appears to be reflected in the growth in the number of its adherents: as the table above shows, Protestantism grew by $333.7 \%$ between 1962 and 1970, while Catholicism grew just 32.0\%.

38 Andrew Kim, 'Characteristics of Religious Life in South Korea: A Sociological Survey', Review of Religious Research, 43:4 (2002), 291-310, at p.294. Konstantine Vassiliev, 'Industrialization and Christianity: The Twin Engines of Korean Modernity', p.9o.

40 Ibid., p.9o.

41 Kirsteen Kim, 'Christianity's Role in The Modernization and Revitalization of Korean Society in the Twentieth-Century', p.227.

42 Ibid., p.227.

43 Ibid., p.91.

44 Grace Davie, Europe: The Exceptional Case, p.128.

45 Sung-Ho Kim, 'Rapid Modernisation and The Future of Korean Christianity', p.3o.

46 Kirsteen Kim, 'Christianity's Role in the Modernization and Revitalization of Korean Society in The Twentieth-Century', p.226. 
While a nexus between Christianity and economic growth is harder to discern in China, its potential to stimulate economic growth has been recognised. Christopher Marsh, who spent considerable time conducting fieldwork at grassroots and official levels in China, observes, 'Chinese scholars and policymakers have been keenly interested in this relationship and... the perceived economic beliefs of Christian belief'. ${ }^{47}$ Indeed, though scholars at Peking University concede that studies on the effects of Protestantism in generating economic activity in non-Western societies are 'fraught with questions of causality, ${ }^{\prime} 8$ they argue that there is a significant, positive correlation between Protestant missionary activity in the twentieth century and China's economic, educational, and healthcare outcomes in $2000 .{ }^{49}$ In particular, they highlight the impact of Protestant missions in less developed areas of China, which 'fostered the accumulation' of human capital and social values 'that have been conducive to modern economic growth. ${ }^{50}$ This study complements South Korea's example and suggests that there is a perception in East Asia (and possibly, a reality, if its findings are correct) that Christianity can be a means to support and encourage economic activity.

\section{Catholicism and Democratisation}

Christianity is credited by Joachim Gentz for playing 'a pivotal role in national politics far beyond what the "minority" status would suggest' in galvanising popular support for South Korea's democratisation. ${ }^{51}$ Following rapid economic growth, by 1970 South Koreans were, as Sung-Ho Kim outlines, 'beginning to experience the negative aspects of modernisation', such as 'class polarisation', 'regional differences in development', alongside continued oppression by 'an autocratic regime. ${ }^{52}$ Despite wariness of social change due to its association with the North, liberal Protestant movements and Catholicism were embraced as means to resist the authoritarian Yusin regime. ${ }^{53}$ In the table above, the growth rate during this period is calculated over fifteen years (1970-1985)

Christopher Marsh, Religion and the State in Russia and China (New York: Continuum, 2011), p.240.

Yuyu Chen, Hui Wang, and Se Yan, 'The Long-Term Effects of Protestant Activities in China,', CEH Discussion Papers 025 (Canberra: Centre for Economic History, Research School of Economics, Australian National University, 2014), 1-57, at p.2.

49 Ibid., p.4.

5o Ibid., p.5.

$5^{1} \quad$ Joachim Gentz, 'The Religious Situation of the State in Asia', in Julius Bautista, Francis Khek Gee Lim, eds, Christianity and the State in Asia (London: Routledge, 2009), p.4.

$5^{2} \quad$ Sung-Ho Kim, 'Rapid Modernisation and The Future of Korean Christianity', p.31.

53 Grace Davie, Europe: The Exceptional Case, p.127. 
rather than the previous eight-year increment (1962-1970) due to scarce data. However, one can still discern a change in the religious growth rate patterns, which may reflect this growing interest in Catholicism: between 1970-1985 Catholicism grew $140.1 \%$ (up considerably from $32.0 \%$ the previous decade), while Protestant growth slowed to $103.3 \%$, still a relatively fast rate.

Christianity played an active role in opposing the military regime and providing rhetorical support for the democratisation movement in South Korea. Minjung Theology, literally, 'People's Theology', though largely disseminated by liberal Protestants, was inspired by Catholic Liberation Theology. Notably, however, it did not have a similar emphasis on Marxist ideology, ${ }^{54}$ but focused on interpreting salvation 'in terms of ordinary people's struggles against oppressive structures. ${ }^{55}$ It directly challenged the Yusin's justification that 'undemocratic and extraordinary measures' were necessary 'to improve the living conditions of the masses. ${ }^{56}$ As outlined in the 1973 Theological Declaration of Korean Christians, Christians argued that the government's economic policies made South Koreans 'victims of severe exploitation and social and economic injustice... So-called "economic development" in Korea turned out to be the conspiracy of a few rulers against the poor people.57 The Minjung theologians' concerns were widely disseminated in both secular and religious contexts, which bolstered the democratic cause and generated momentum for social and political change. After oscillating between nominal democracy and military rule, South Korea finally stabilised as a liberal democracy in 1993 following the country's first free election of President Kim Young-sam, whose membership of the Chunghyung Presbyterian Church provided him with critical political support. ${ }^{58}$

The influence of Minjung Theology on South Korean politics challenges Bruce's argument that 'religious interest groups can be effective in civil society only when they accept the privatisation of their distinctive religious beliefs and move on to secular ground. 59 With reference to 'the new Christian right

\footnotetext{
54 Joachim Gentz, 'The Religious Situation of the State in Asia', p.5.

55 Ibid., p.5.

56 Paul Yunsik Chang, 'Carrying the Torch in the Darkest Hours: The Sociopolitical Origins of Minjung Protestant Movements', in Robert E. Buswell, Timothy S. Lee, eds, Christianity in Korea (Hawaii: University of Hawaii Press, 2006), 195-220, p.200.

'1973 Theological Declaration of Korean Christians', in Paul Yunsik Chang, Carrying the Torch in the Darkest Hours: The Sociopolitical Origins of Minjung Protestant Movements, p.214.

$5^{8} \quad$ Younggi Hong, 'Evangelicals and the Democratisation of South Korea Since 1987', in David Halloran Lumsdaine, ed, Evangelical Christianity and Democratisation in Asia (Oxford: Oxford University Press, 2009), p.202. 
in the U.S.', he contends that religious groups can only be successful in influencing secular society if they present 'their case in secular terms. ${ }^{60}$ Minjung Theology, by contrast, presented secular issues in religious terms. Far from being detached from the public sphere, the strength of the theological challenge by Christian institutions dismantled Park's justification for the Yusin Regime in a way that garnered public attention.

The Communist Party of China (CCP) has long been wary of religion's ability to elicit political change. For example, there was a perception amongst CCP officials that religion had played a decisive role in bringing about the collapse of the Soviet Union. At the time, the Director of the Bureau of Religious Affairs, Ye Xiaowen, identified two means by which he believed religion may have elicited political change. First, 'religion plays the role of a sacred banner under which the nation fights national oppression'.61 Indeed, Minjung Theology appears to have played precisely this role during the democratisation of South Korea. Second, religion may be used as a vehicle through which foreign actors may be able to influence domestic politics. ${ }^{62}$

These concerns have extended to the present day. President Xi Jinping has taken an even more hard-line position on religious freedom than his predecessors. China's Policies and Practices on Protecting Freedom of Religious Belief, published in 2018, is the most recent policy on religion. Notably, the paper cautions against religious activities that 'endanger social stability, national unity and state security', which exemplifies the CCP's concern about religion's potential to galvanise social change. ${ }^{63}$ Indeed, Marsh notes, 'one need not look far for bolder statements calling for Christians to engage in the political realm'64 that describe social justice movements as 'a Christian's duty'.65 That Christianity may present a rival world order that challenges the CCP's own is still seen as a real threat by the government, which may explain Xi's harsh policies against Christians (and other religious groups). ${ }^{66}$ Though Christianity in China has

\footnotetext{
6o Ibid., p.21.

61 Ye Xiaowen, 'China's Current Religious Question: Once Again an Inquiry into the Five Characteristics of Religion', (1996); reprinted in China: State Control of Religion (New York Human Rights Watch/Asia, 1997), p.13o.

62 Ibid., p.133.

63 "China's Policies and Practices on Protecting Freedom of Religious Belief", The State Council Information Office of the People's Republic of China (2018) http://www.scio.gov.cn/ zfbps/32832/Document/1626734/1626734.htm.

64 Christopher Marsh, Religion and the State in Russia and China, p.23o.

65 Ibid., p.231.

66 Eleanor Albert, 'Religion in China', Council on Foreign Relations, (2018) https://www.cfr. org/backgrounder/religion-china.
} 
never had the opportunity to elicit political change akin to that encouraged by the South Korean churches, its potential is recognised.

\section{The Efficacy of Chinese and South Korean Christianity as Counterexamples}

Even the more nuanced secularisation theses are based on a comparative analysis of the role of religion in history and the present day, specifically in Europe. Indeed, Bruce cautions against applying his theory to non-European contexts, writing, 'an account of the past in Western Europe... is only generalisable to other settings to the extent that the specific elements are reproduced in those settings.' ${ }^{67}$ Bruce and Dobbelaere could, therefore, argue that Christianity in South Korea and China cannot be used as counterexamples against their theories as they apply on a macro-level. This highlights the cultural specificity and a limitation of their theories. The basis of comparison they use - the change from the European Church's hegemonic position to a comparatively limited role in the public sphere - entails that the theorists invariably conclude that modernity has had a negative impact on the position of religion in society. There is little consideration of the possibility that religious institutions can influence the public sphere even if they are not hegemonic.

The starting point for Christianity in South Korea and China is, of course, completely unlike the position the Catholic Church once occupied in medieval Europe. Christian South Koreans make up 30\% of the population ${ }^{68}$ and Christian Chinese, 2.5\% ${ }^{69}$ As minoritarian groups, their functioning in society is partly determined by negotiation with 'the temporal authority of state structures'; they have never had the power relations that European churches have enjoyed..$^{70}$ However, that Christians have been able to have decisive political and social influence despite their minoritarian status may suggest that the negative metric of the Secularisation Thesis ought to be recast.

To these ends, José Casanova's discussion of the 'deprivatisation' of religion is helpful. ${ }^{71} \mathrm{He}$ posits that although religious institutions are no longer hegemonic, this does not necessarily mean that they are relegated to the private sphere; they are still able to be present in 'the undifferentiated public sphere

67 Steve Bruce, in Russell Sandberg, ed, Religion, Law and Society, p.126.

68 Kirsteen Kim, 'Christianity's Role in the Modernization and Revitalization of Korean Society in the Twentieth-Century', p.214.

69 Christopher Marsh, Religion and the State in Russia and China, p.231.

70 Joachim Gentz, 'The Religious Situation of the State in Asia', p.11.

71 Jose Casanova, Public Religions in the Modern World (Chicago: University of Chicago Press, 1994), p.65. 
of civil society to take part in the ongoing process of contestation, discursive legitimation, and redrawing of the boundaries.' ${ }^{72}$ Though Christianity has never been the hegemon in East Asian societies, the South Korean Church has played a demonstrable role (and the potential of the Chinese Church has been recognised at the highest government level) in shaping the public sphere with regards to economic activity and political change. Thus, rather than, as Bruce and Dobbelaere do, fixate on negative historical comparisons, it is perhaps helpful to use South Korea and China's examples to recast the Secularisation Thesis (as it applies to Europe, as well as other regions) more positively so that it considers that religion has a changed rather than lost role in society, and can still be profoundly impactful on a macro-level.

The experience in South Korea therefore challenges the Secularisation Thesis on a macro-level in two ways. First, the demonstrable influence of Christianity in South Korea's recent history shows that religion and modernity are not incompatible; indeed, they can have a positive, symbiotic relationship. Second, it suggests that religion does not need to be institutional and hegemonic to have influence in the public sphere.

\section{Meso-Level: Societalisation}

'Societalisation', first described by Bryan Wilson and elaborated upon by Bruce, refers to 'the process by which life is increasingly enmeshed and organised, not locally but societally' ${ }^{73}$ Both theorists assume the Durkheimian understanding of religion as 'something eminently social, ${ }^{74}$ which draws its strength from a community. When society becomes urbanised, they argue, it fractures and becomes organised at a state, rather than local, level. Religion, which was particularly active in the life and organisation of local communities, is therefore 'shorn of its functions' and rendered obsolete. ${ }^{75}$

This is not borne out in South Korea and China, which have experienced concurrent growth of their urban and Christian populations. South Korea's urban population grew from $28 \%$ in 1960 to $57.2 \%$ in $1980,{ }^{76}$ while Christian numbers swelled from 1.3 million to 8.4 million. ${ }^{77}$ Similarly, China's Christian

$72 \quad$ Ibid., pp. $65^{-66 .}$

73 Steve Bruce, God Is Dead: Secularisation in The West, p. 47.

74 Emil Durkheim, The Elementary Forms of Religious Life, p. 10.

75 Steve Bruce, God Is Dead: Secularisation in The West, p.13.

76 Sung-Ho Kim, 'Rapid Modernisation in the Future of Korean Christianity', p.28.

77 Ibid., p.27. 
population has steadily increased over the past four decades, while its urban population has grown from $17.9 \%$ to $58.5 \% .{ }^{78}$ Notably, many of these adherents are not private believers: Andrew Kim characterises South Korean Christians as typically 'active religious participants', 79 while Yang describes 'churches filled beyond capacity' during his fieldwork in China. ${ }^{80}$

Churches in both countries provide vital communal and welfare support to (particularly elderly) individuals, many of whom are adversely affected by the impacts of modernisation on society. Until recently, familial arrangements in China and South Korea entailed the co-residence of elderly parents with their adult children, even after marriage. This structure provided, as Patricia Bell outlines, 'physical, psychological and financial support' for the elderly. 81 However, many young Chinese and South Koreans now live in nuclear families in cities. In China, this issue is compounded by the '4-2-1 problem' surrounding the 'one-child policy': only children are responsible for looking after aging parents and grandparents without help they may have otherwise had if they had siblings. ${ }^{82}$ Thus, while the elderly do not necessarily 'lack... support from family members', this profound social and cultural change means that those who live alone have more limited access to the support traditionally provided by extended-family living arrangements. ${ }^{83}$

In South Korea, churches provide communal support to individuals who have 'had difficulty in establishing their social loci in the modern world' ${ }^{84}$ Kyuhoon Cho observes that the elderly are drawn to conservative Protestant churches as 'a potent resource for the recovery of direction and empowerment' ${ }^{85}$ and 'bastions' for traditional values and counter-reform. ${ }^{86}$

It is important not to overestimate the role religion can play on a meso-level in Chinese society. Freedom of religious expression is guaranteed in the Chinese

78 'China's Long and Winding Road to Quality Urbanisation', The Telegraph (2018) https:// www.telegraph.co.uk/china-watch/business/urbanisation-in-china/.

79 Andrew Kim, 'Characteristics of Religious Life in South Korea: A Sociological Survey', p.296.

8o Fenggang Yang, Religion in China: Survival and Revival Under Communist Rule, p.144.

81 Patricia Bell, 'The Impact of Rapid Urbanisation on South Korean Family Composition and the Elderly Population in South Korea', Population Review, 43:1 (2004), 50-6o, at p.51. Z Zhai, 'Urbanisation and the aging of urban population in China trend and countermeasures', Chinese Journal of Popular Science, 9:1 (1997), 35-44.

83 Patricia Bell, 'The Impact of Rapid Urbanisation on South Korean Family Composition and the Elderly Population in South Korea', p.57.

84 Kyuhoon Cho, 'Another Christian Right? The Politicization of Korean Protestantism in Contemporary Global Society', Social Compass, 61 (2014), 310-327, at p.315.

85 Ibid., p.315.

86 Ibid., p.319. 
Constitution, but with the caveats that 'the state protects normal religious activities' and that 'no one may make use of religion to engage in activities that disrupt public order, impair the health of citizens or interfere with the educational system of the state. ${ }^{87}$ In other words, religious practice is only permitted in government-sanctioned organisations and places of worship, and so long as it serves the interests of the state. Religion is therefore highly regulated in Chinese society, particularly in the spheres of education and social service.

However, there are instances of Chinese churches providing practical care for the vulnerable, which suggests that they do have an (albeit limited) impact on a meso-level. For example, $20 \%$ of care homes in Hangzhou are operated by non-governmental organisations, many of which are Christian-funded and run. ${ }^{88}$ This is consistent with the Church's broader philanthropic presence in Chinese society. Churches mobilised, following the 2008 Sichuan and the 2012 Yunnan earthquakes, to provide financial and practical support to victims. Their actions contrasted with the CCP's slow response, which drew public criticism. ${ }^{89}$ This illustrates the role of the Chinese Church in providing social support given the often inadequate and imbalanced Chinese welfare state, and hence its popular appeal. ${ }^{90}$

Bruce contends that there can be temporary exceptions to the Secularisation Thesis when seismic social change occurs, so the incidence of church involvement in social affairs is not necessarily inconsistent with his thesis. Although 'industrialisation and urbanisation tend in the long-run to undermine traditional community', he writes, 'in the short-term they can be associated with an increase in attachment to religious bodies'.91 $\mathrm{He}$ cites Irish immigrants in 19th century Britain coalescing around the Catholic Church upon their arrival as an example. ${ }^{92}$ Similarly, perhaps, people facing social and cultural change in South Korea and China have been attracted to the communities and support religion offers. However, unlike Irish immigrants who were already Catholic, Chinese and South Korean Christians are often new adherents to the faith. Following the Sichuan earthquake, new church membership in the region

87 The Constitution Law of the People's Republic of China (Beijing, 1982), Chapter 2, Article 32, Clause 3 .

88 'New Homes for The Old', The Economist (2012), https://www.economist.com/ china/2012/04/21/new-homes-for-the-old.

$89 \quad$ Jillian Kay Melchior, 'Charity Begins in China', The Washington Examiner (2012) https:// www.washingtonexaminer.com/weekly-standard/charity-begins-in-china.

$90 \quad$ Ken Wills, 'Seeking Balance', Finance and Development, 55:4 (2018) International Monetary Fund, 20-23, at p.22.

91 Steve Bruce, God Is Dead: Secularisation in The West, p.36.

$92 \quad$ Ibid., p.35. 
increased by a third. ${ }^{93}$ This suggests the South Korean and Chinese experience may not be a temporary 'exception' to Bruce's thesis so much as a new phenomenon of Christian growth. Further, even if Bruce's substantive argument holds, the incidence of religious growth is unlikely to be 'short-term'. For, unless the Chinese and South Korean states are able to provide entirely for the elderly and vulnerable, which does not seem likely to happen soon, churches will continue to play an important social role.

Perhaps, insufficient time has passed to test Bruce's 'cultural transition' theory in South Korea and China. However, evidence to date suggests that far from urbanisation leading to the fragmentation of religious communities, churches have neither been 'shorn of their functions' nor rendered obsolete, ${ }^{94}$ but continue to play important roles at the meso-level in the public sphere.

\section{Micro-Level: Rationalisation}

Secularisation theorists posit that an increase in scientific and rational thinking leads to a decline in personal piety. Dobbelaere writes, 'the process of rationalisation' is a 'prerequisite for any industrial society of the modern type' but that it is also 'the decisive variable for secularisation. ${ }^{95}$ To unpack this idea, it is helpful to draw on Bruce and Weber. Bruce argues that science and religion are not necessarily 'zero-sum'; 96 'science and technology do not create atheists', but rather, they 'reduce the frequency and seriousness with which people attend to religion'. ${ }^{97}$ This echoes Weber's concept of disenchantment. The increase in scientific rational thinking, he suggests, leads to the perception that 'one can, in principle, master all things by calculation'. There are no longer 'mysterious incalculable forces', and religion thus loses its previous role in explaining worldly matters. ${ }^{98}$

The impact of rationalisation on religiosity is understood to be gradual, but it is posited that, ultimately, religion is 'doomed to disappear'. ${ }^{99}$ In 1978, Jivko Ochavkov predicted that Soviet Bulgaria would undergo such a

93 Hazel Southam, 'Converted After China's Earthquake', The Times (2013), https://www. thetimes.co.uk/article/converted-after-chinas-earthquake-dm6jwos7nmm.

94 Steve Bruce, God Is Dead: Secularisation in The West, p.13.

95 Karel Dobbelaere, Secularisation: An Analysis at Three Levels, p.31.

96 Steve Bruce, God Is Dead: Secularisation in The West, p.26.

97 Ibid., p.27.

98 Max Weber, 'Science as a Vocation', in H.H. Gerth and C. Wright Mills, eds, and trans., From Max Weber, Essays in Sociology (London: Routledge, 1948), p.139.

99 Jivko Ochavkov, in Karel Dobbelaere, Secularisation: An Analysis at Three Levels, p.42. 
transformation. He argued that while there would still be adherents amongst older generations, amongst the youth, political ideologies (i.e. Communism) and rational thinking would replace religion. ${ }^{100}$ Ochavkov's predictions were never realised. Following the collapse of the Soviet Union, religious practice in Bulgaria revived across all demographics. ${ }^{101}$ In China, a study by China Normal University in 2010 found that $62 \%$ of Christians polled were aged 16-39, while $9.6 \%$ were over $55{ }^{102}$ This striking statistic shows that religious growth in China is particularly concentrated among its youth, despite their having grown up under an atheist, Communist regime, and in an economically dynamic age permeated by scientific thinking. This suggests that a more rational, scientific-oriented society does not necessarily dispose of religion.

\section{The Strength of Alternative Explanations}

There are two main conceptual challenges to religion in China. The first is from rational and scientific thinking, which, supposedly, renders religious explanations implausible, culminating in the 'disenchantment of the world'.103 Weber's theory of 'disenchantment' expressed in his essay Science as a Vocation is more nuanced than what Bruce and Dobbelaere conceptualise, however. He convincingly argues that there remain aspects of life that cannot be satisfactorily explained in rational terms: 'material science gives us an answer to the question of what we must do if we wish to master life technically', but does not necessarily answer 'whether we should and do wish to master life technically and whether it ultimately makes sense to do so'.104

The second is the ideological challenge from Communism, which the ССP considers 'a competitive alternative to religious beliefs' to the extent that they have 'deliberately tried to replace conventional religion with the secular, atheistic belief system of Communism'. ${ }^{105}$ Although they do not describe it in this way, the CCP's vision may be understood by reference to Durkheim's notion of the 'eternal' nature of religion. ${ }^{106} \mathrm{He}$ posits that traditional religion may 'no longer [exercise] the same hegemony as formerly over the system of

\footnotetext{
$100 \quad$ Ibid. p.42.

101 Simeon Evstatiev, 'Milletic Secularism in The Balkans: Christianity, Islam, And Identity in Bulgaria', Nationalities Papers, 47:1 (2019), 87-103.

102 Jiao Wu, 'Religious Believers Thrice the Official Estimate: Poll', China Daily (2007), http:// www.chinadaily.com.cn/cndy/2007-02/o7/content_802861.htm.

103 Max Weber, 'Science as a Vocation', p.139.

104 Ibid., p.144.

105 Fenggang Yang, Religion in China: Survival and Revival Under Communist Rule, p.21.

106 Emil Durkheim, The Elementary Forms of Religious Life, p.427.
} 
ideas', but that, as an 'eminently social' 107 concept, it will simply be replaced by another 'rival power', ${ }^{108}$ such as, perhaps, Communism. However, far from this, Communism in China has failed to eradicate the 'old gods' of traditional religion, which remain powerful motifs. ${ }^{109}$ As Yang outlines, although 'some people have settled for Communism', many find that it does not '[satisfy] their spiritual needs.'110

An assumption made by secularisation theorists is that science offers more plausible explanations for all aspects of life. However, despite the increase in rational explanations and alternative ideologies that, in the case of Communism, have been forcibly imposed, many Chinese continue to turn to Christianity (and other religions). The endurance of religion despite these challenges is expressed in the 1981 Chinese novella When the Sunset Clouds Disappear, which follows the journey of a Red Guard who is disillusioned with Marxist and scientific dialectics. Following an enlightening discussion with a Tibetan Buddhist monk, he concludes that only religion can address his moral dilemmas. ${ }^{111}$ Similarly, Tony Lambert describes how, in the aftermath of the 1989 Tiananmen Square massacre, '20o students came literally knocking of the door of the local Three-Self Patriotic Movement Church seeking answers to their anguished questions'.12 Thus, Weber's analysis has force: traditional religions are still invoked to provide spiritual meaning and answer moral questions to which neither scientific rationalism nor Communism seem to have provided adequate answers. This challenges the argument that modernity leads to the 'disenchantment of the world'.113 In contradistinction, many in China, most notably the youth, seem to be looking for ways to re-enchant their world.

\section{Implications for the Secularisation Thesis}

Theorists, such as Dobbelaere, may respond that religion's flourishing in the private sphere simply 'confirms' the Secularisation Thesis. ${ }^{114}$ Indeed, Bruce characterises religion as 'a singularly resilient phenomenon which is likely

\footnotetext{
107 Ibid., p.10.

108 Ibid., p.431.

109 Ibid., p.427.

110 Fenggang Yang, Religion in China: Survival and Revival Under Communist Rule, p.139.

111 Li Ping, When the Sunset Clouds Disappear (Beijing: China Youth Publishing House Beijing, 2002).

112 Fenggang Yang, Religion in China: Survival and Revival Under Communist Rule, p.148.

113 Max Weber, 'Science as a Vocation', p.139.

114 Karel Dobbelaere, 'China Challenges Secularisation Theory', Social Compass, 56:3 (2009), p.363.
} 
to survive as privatised belief and practice'.115 It is, he argues, 'precisely the claim of the Secularisation Thesis that religious belief and practice will tend to become more individualised, fragmented, and privatised'. ${ }^{116}$ If religious institutions are no longer relevant in broader society and all that is left is ' $m e$ and my experiences', society can be said to be secularised. ${ }^{117}$

By way of direct rebuttal, as previously outlined, churches in South Korea and China play significant roles in their respective public spheres on both macro- and meso-levels. Casanova outlines a prevailing belief among secularisation theorists that privatised religion is 'invisible'; that is, 'marginal and irrelevant from a societal point of view'.118 The CCP's stringent regulation of it throughout society suggests, however, that they do not believe that it is either 'marginal' or 'irrelevant.' 119

Further, that religion in China is largely conducted privately ${ }^{120}$ is likely due to official opposition and heavy regulation. In his economic theory-based approach to the study of religion in China, Yang argues, 'church attendance is affected by the quality of the religious market'. ${ }^{121}$ While theoretically, more stringent regulation will reduce attendance, the growing number of adherents demonstrates that it still 'cannot effectively reduce religion', but simply complicates the religious market by 'pushing religious organisations and believers into the black and grey markets.' ${ }^{22}$ Thus, the privatisation of religion in China is more likely due to the government's fastidious regulation than the result of modernity and rationalisation.

\section{The Potential for Secularisation in South Korea and China}

In South Korea and China industrialisation, urbanisation, societalisation, and rationalisation have not precipitated the decline of religion; indeed, at times, these factors seem to invigorate religious practice. However, there has been a slow-down in the growth rate of Christianity in South Korea in recent years, which ought to be reflected upon. As shown in the table above, the growth

\footnotetext{
115 Steve Bruce, God Is Dead: Secularisation in The West, p.21.

116 Ibid., p.22.

117 Karel Dobbelaere, 'China Challenges Secularisation Theory', p.363.

118 Jose Casanova, Public Religions in the Modern World, p.35.

11 Liao Xianghui, 'China: Some Exceptions of Secularisation Thesis', Religion, 10:56 (2019), 1-19, at p.8.

120 Christopher Marsh, Religion and the State in Russia and China, p.26o.

121 Fenggang Yang, Religion in China: Survival and Revival Under Communist Rule, p.11.

122 Ibid., p.122.
} 
rates of both Protestantism and Catholicism slowed between 1985-2015. Protestantism experienced negative growth between 1995-2005, followed by a relatively slow growth rate of $12.3 \%$ between $2005^{-2015}$, while Catholicism experienced a slower growth rate between 1995-2005, and negative growth between 2005-2015. This is consistent with a broader trend in religious adherence in South Korea: in the same time frame, Buddhism has also experienced periods of slow and negative growth. ${ }^{123}$

The plateauing of Christian growth coincides with significant stability in South Korea's economic and political spheres. It may be posited that stability and prosperity are linked to a decline in religiosity, which is an argument that Bruce also forwards: 'increasing prosperity reduces religious fervour'.124 Two discernible social changes have been precipitated by this new stability that may have impacted religion. First, as Sung-Ho Kim observes, following the transition to democracy and continued economic growth, 'South Koreans began, relatively speaking, to experience greater psychological stability'. ${ }^{125}$ As already outlined with reference to private religiosity in China, people often turn to religion in times of hardship. With relative stability, South Koreans may have felt less need to turn to religion for communal support and soul-searching. Second, with increased prosperity, patterns of daily life have changed. For example, Byong-Suh Kim notes that the South Korean leisure industry has grown particularly quickly. With more options available, 'no longer is the church the place where people come to spend their leisure hours' ${ }^{126}$

By contrast, there is consensus that Christianity is still growing at a relatively fast rate in China. ${ }^{127}$ Yet, China's political climate is more akin to South Korea's military dictatorship era, when, as Byong-Suh Kim outlines, 'political instability and social unrest' precipitated 'the explosive growth of the Korean Protestant Church.' ${ }^{128}$ Perhaps, as was the case in South Korea, religion in modern China remains appealing because it provides much-needed support and respite from high degrees of political, social and psychological repression. Thus, to extrapolate this argument in terms of the Secularisation Thesis, one

\footnotetext{
123 Statistics Korea, Number of Religious People Affiliated to Buddhism in South Korea from 1985 to 2015 (Seoul: Ministry of Culture, Sports and Tourism, 2020).

124 Steve Bruce, God Is Dead: Secularisation in The West, p.25.

125 Sung-Ho Kim, 'Rapid Modernisation and The Future of Korean Christianity', p.29.

126 Byong-Suh Kim, 'Modernisation and the Explosive Growth and Decline of Korean Protestant Religiosity', in Robert E. Buswell, and Timothy S. Lee, eds, Christianity in Korea (Hawaii: University of Hawaii Press, 2006), 209-329, at p.326.

127 Fenggang Yang, Religion in China: Survival and Revival Under Communist Rule, p.11.

128 Byong-Suh Kim, 'Modernisation and the Explosive Growth and Decline of Korean Protestant Religiosity', p.325.
} 
may posit that the decline of the significance of religion occurs when widespread social stability is achieved.

\section{Conclusion}

The most fragile secularisation theses seek to construct universal theories on the basis of ethno-centric evidence. Even the more nuanced theses, such as those proposed by Bruce and Dobbelaere, are difficult to apply in non-Western contexts that have experienced the same elements of modernity - industrialisation, societalisation, urbanisation, and rationalisation - that the theorists argue have caused secularisation in Europe. South Korea's example shows that religion can be socially significant in a modern industrial context even when it does not occupy a hegemonic position. This suggests that religion and industrialisation can have a symbiotic relationship. As such, the Secularisation Thesis might validly be recast to reflect Casanova's notion of the 'deprivatisation' of religion, recognising that religion can continue to have social significance even if it is not institutionally hegemonic. ${ }^{129}$ Rather than fracture religious communities, urbanisation and societalisation can embolden them on a meso-level. Though they concede that religion can continue to operate in the private sphere, the endurance and growth of religious practice especially amongst the youth despite (and indeed, because of) widespread scientific knowledge and the alternative ideology of Communism in China challenges both theorists' notions that rationalisation leads to an eventual decline of religion on a micro-level. Therefore, Bruce's so-called 'testable explanations'130 for his Secularisation Thesis are not supported when analysed in relation to China and South Korea. An early analysis of South Korea's plateauing religious growth, in comparison with the continued rise of religiosity in China, may suggest that other factors are at play, and that widespread social stability and prosperity better explain a decline in the social significance of religion.

\section{Bibliography}

Albert, Eleanor. "Religion in China." Council on Foreign Relations, 2018 https://www.cfr. org/backgrounder/religion-china [accessed 1 March 2020].

Bell, Patricia. "The Impact of Rapid Urbanisation on South Korean Family Composition and the Elderly Population in South Korea." Population Review 43 (1) (2004), 50-6o.

129 Jose Casanova, Public Religions in the Modern World, p.65.

130 Steve Bruce, God Is Dead: Secularisation in The West, p.38. 
Berger, Peter. The Sacred Canopy: Elements of A Sociological Theory of Religion (New York: Anchor Books, 1967).

Bruce, Steve. God Is Dead: Secularisation in The West (London: Blackwell Publishing, 2002).

Casanova, Jose. Public Religions in the Modern World (Chicago: University of Chicago Press, 1994).

Chang, Paul Yunsik. 'Carrying the Torch in the Darkest Hours: The Sociopolitical Origins of Minjung Protestant Movements." In Christianity in Korea, eds. , Robert E. Buswell, , Timothy S. Lee (Hawaii: University of Hawaii Press, 2006), 195-220.

“China's Long and Winding Road To Quality Urbanisation." The Telegraph, 2018, https:// www.telegraph.co.uk/china-watch/business/urbanisation-in-china/ [accessed 1 March 2020].

"China's Policies and Practices on Protecting Freedom of Religious Belief." The State Council Information Office of the People's Republic of China, 2018). http://www.scio. gov.cn/zfbps/32832/Document/1626734/1626734.htm [accessed 19 May 2020].

Cho, Kyuhoon. "Another Christian Right? The Politicization of Korean Protestantism in Contemporary Global Society." Social Compass 61 (2014), 310-327.

Clammer, John. "Secularization and Religious Change in Contemporary Asia." Asian Journal of Social Science 12 (1984), 49-58.

Davie, Grace. Europe: The Exceptional Case (London: Darton, Longman and Todd, 2002).

Dobbelaere, Karel. Secularisation: An Analysis at Three Levels (Brussels: P.I.E. - Peter Lang, 2002).

Dobbelaere, Karel. "China Challenges Secularisation Theory." Social Compass 56 (3) (2009), doi.org/10.1177/oo377686o9338758.

Durkheim, Emil. The Elementary Forms of Religious Life. trans. Joseph Ward Swain (London: George Allen \& Unwin, 1915).

Evstatiev, Simeon. "Milletic Secularism in The Balkans: Christianity, Islam, and Identity in Bulgaria." Nationalities Papers 47(1) (2019), 87-103.

Gao, Shining. "The Sacred Canopy in China." Journal of The American Academy of Religion 85 (2017), 1132-1136.

“GDP Ranked by Country 2020." World Population Review, 2020, http:// worldpopulationreview.com/countries/countries-by-gdp/ [accessed 1 March 2O2O]. Gentz, Joachim. "The Religious Situation of the State in Asia." In Christianity and the State in Asia, eds. Bautista Julius, and Gee Lim Francis Khek (London: Routledge, 2009).

Hazzan, Dave. “Christianity and Korea." The Diplomat, 2016 https://thediplomat. com/2016/o4/christianity-and-korea/ [accessed 28 March 2020].

Hong, Younggi. "Evangelicals and the Democratisation of South Korea Since 1987." In Evangelical Christianity and Democratisation in Asia, ed. Halloran Lumsdaine David (Oxford: Oxford University Press, 2009). 
Industrial Development Report (Vienna: United Nations Industrial Development Organisation, 2017).

Kamm, Henry. "Pope Calls On China to Renew Its Relations with The Church." New York Times (1982).

Kim, Andrew. "Characteristics of Religious Life in South Korea: A Sociological Survey", Review of Religious Research, 43:4 (2002), 291-310.

Kim, Byong-Suh. "Modernisation and the Explosive Growth and Decline of Korean Protestant Religiosity." In Christianity in Korea, eds. Robert E. Buswell , and Timothy S. Lee (Hawaii: University of Hawaii Press, 2006), 209-329.

Kim, Kirsteen. "Christianity's Role in The Modernization and Revitalization of Korean Society in The Twentieth-Century." Religion 4 (2010), 212-236.

Kim, Kwan S. "The Korean Miracle (1962-1980) Revisited: Myths and Realities in Strategy and Development." Helen Kellogg Institute for International Studies (Notre Dame: University of Notre Dame, 1991).

Kim, Sung-Ho. "Rapid Modernisation and The Future of Korean Christianity." Religion 32 (2002), 27-37.

Li, Ping. When the Sunset Clouds Disappear (Beijing: China Youth Publishing House Beijing, 2002).

(礼平, 晚霞消失的时候, 北京：中国青年出版社：2002).

Liao, Xianghui. “China: Some Exceptions of Secularisation Thesis." Religion 10 (56) (2019), 1-19.

Marsh, Christopher. Religion and the State in Russia and China (New York: Continuum, 2011).

Melchior, Jillian Kay. "Charity Begins in China," The Washington Examiner, 2012 https://www.washingtonexaminer.com/weekly-standard/charity-begins-in-china [accessed 28 March 2020].

"New Homes for The Old." The Economist, 2012, https://www.economist.com/ china/2012/04/21/new-homes-for-the-old [accessed 28 March 2020].

Revision of World Urbanization Prospects (Vienna: United Nations Industrial Development Organisation, 2018).

Sandberg, Russell. Religion, Law and Society (Cambridge: Cambridge University Press, 2014).

Southam, Hazel. “Converted After China's Earthquake," The Times, 2013 https:// www.thetimes.co.uk/article/converted-after-chinas-earthquake-dm6jwos7nmm [accessed 28 March 202O].

Statistics Korea. Number of Religious People Affliated to Buddhism in South Korea from 1985 to 2015 (Seoul: Ministry of Culture, Sports and Tourism, 2020).

Statistics Korea. Number of Religious People Affiliated to Catholicism in South Korea from 1985 to 2015 (Seoul: Ministry of Culture, Sports and Tourism, 2020). 
Statistics Korea. Number of Religious People Affiliated to Protestantism in South Korea from 1985 to 2015 (Seoul: Ministry of Culture, Sports and Tourism, 2020).

The Constitution Law of the People's Republic of China (Beijing, 1982).

The Pew Forum on Religion and Public Life. "Global Christianity: A Report on the Size and Distribution of the World's Christian Population." Pew Research Centre, 2011.

United Nations Department of Economic and Social Affairs. "Population Dynamics." 2009 https://population.un.org/wpp/ [accessed 28 March 2020].

Vassiliev, Konstantine. "Industrialization and Christianity: The Twin Engines of Korean Modernity." Korea Review of International Studies (2005), 79-102.

Weber, Max. "Science as a Vocation." In From Max Weber, Essays in Sociology, eds. trans. H.H. Gerth and C. Wright Mills (London: Routledge, 1948).

Wills, Ken. "Seeking Balance." Finance and Development 55 (4) (International Monetary Fund, 2018), 20-23.

Wu, Jiao. "Religious Believers Thrice the Official Estimate: Poll." China Daily, 2007 http://www.chinadaily.com.cn/cndy/2007-02/o7/content_802861.htm [accessed 1 March 2O2O].

Xiaowen, Ye. “China's Current Religious Question: Once Again an Inquiry into the Five Characteristics of Religion." 1996 (reprinted in China: State Control of Religion) (New York: Human Rights Watch/Asia, 1997).

Yang, Fenggang. Religion in China: Survival and Revival Under Communist Rule (Oxford: Oxford University Press, 2012).

Yuyu Chen, Hui Wang, and Se Yan, 'The Long-Term Effects of Protestant Activities in China', CEH Discussion Papers o25 (Canberra: Centre for Economic History, Research School of Economics, Australian National University, 2014), 1-57. doi:10.2139/ ssrn.2186818.

Zhai, Z. "Urbanisation and the aging of urban population in China trend and countermeasures." Chinese Journal of Popular Science 9 (1) (1997), 35-44. 